\title{
LIFE SATISFACTION AS DEFINED BY SNAPCHAT USAGE AND ADDICTION CASE STUDY IN KUWAIT
}

\author{
Hasan Abbas \\ Kuwait University, Kuwait
}

\begin{abstract}
Social media is prevalent in today's socialization and communication between individuals. Adopting uses and gratifications framework, the goal of this study is to investigate whether the needs for privacy, entertainment, socialization, and recognition as well as the fear of a negative evaluation are predictors of pathological Snapchat use and levels of depression and life satisfaction. Participants in this study $(N=430)$ took an online survey. The conceptual model was tested using structural equation modeling (SEM). The results show that entertainment needs are the most influential factor in pathological Snapchat use, the fear of a negative evaluation is the most influential factor on depression, and social needs are the most influential on life satisfaction. Importantly, results also revealed that life satisfaction is not impacted neither by pathological use nor depression.
\end{abstract}

Key words: Pathological Snapchat use; Depression; Life satisfaction; Privacy; Entertainment needs; Fear of negative evaluation.

Cite this Article: Hasan Abbas, Life satisfaction as defined by Snapchat usage and addiction Case study in Kuwait, International Journal of Management, 11(12), 2020, pp. 2326-2351.

http://iaeme.com/Home/issue/IJM?Volume=11\&Issue=12

\section{INTRODUCTION}

Snapchat is one of the most popular social networking applications. According to the latest figures, there are almost 3.8 billion social media users around the world. On average, each user has more than eight different social media platforms and spends on average around 2 hours and 24 minutes using social media daily (DATAREPORTAL, 2020). Snapchat's market share among other social media platforms is 382 million active users (DATAREPORTAL, 2020).

Snapchat differs from other social media platforms in that it relies solely on visual communication (images and videos). Since its first introduction by a group of Stanford University students in 2011, it has significantly changed and undergone many improvements and experienced notable growth since then. It introduced features like videos, 24-hour stories, 
and many more in 2013 and beyond those have inspired users to create and develop their own story features.

Social media in general has become an essential part of a Kuwaiti's life. Although Kuwait is a small country with roughly 3 million people, 1.65 million people in Kuwait are considered active users of Snapchat. It is being used by people of all ages and genders and for different reasons (Social Media Insights, 2019). One important use of Snapchat in Kuwait is marketing. Snapchat marketing is a unique way to promote services and products of businesses. Snapchat gives opportunities to users and businesses to take photos, record videos, add text, add drawings, and send them to either controlled recipients or to make them public stories (LeadsKuwait, 2020).

However, the inappropriate and intensive use of social media can cause many negative effects, especially for youngsters and millennials. These applications hamper normal life activities of individuals such as socializing, visiting, working, and so forth. Social media overuse could become an addiction and result in further disastrous results (Bargeron \& Hormes, 2017; Caplan, 2010; Cheever, Moreno, \& Rosen, 2018; Davis, 2001; Foroughi, Iranmanesh, Nikbin, \& Hyun, 2019; Gámez-Guadix, Villa-George, \& Calvete, 2012; Sioni, Burleson, \& Bekerian, 2017; Zimbardo, 1977).

Recently many studies have indicated that social media pathological use badly affects the quality of and satisfaction with life (Correa, Hinsley, \& de Zúñiga, 2010; Foroughi et al., 2019; Longstreet, Brooks, \& Gonzalez, 2018). Studies have shown that depression and addiction mediate the "relation between problematic usage of technology and its outcomes" (Foroughi et al., 2019). Considering the drivers of the pathological use of social networking sites (SNS), several studies show that social and psychological needs can play major roles as intrinsic drivers (Balakrishnan \& Shamim, 2013; Masur, Reinecke, Ziegele, \& Quiring, 2014; Mingchuan, Mengli, Adeel, Lingling, \& Ayesha, 2020). For example, (Foroughi et al., 2019) studies four external factors that affect life satisfaction through internal factors, Facebook addiction, depression, and social anxiety. Those external factors are recognition needs, information needs, social needs, and entertainment needs that are moderated through self-regulation. Brooks (Brooks, 2015) investigates the relation of the effects of the personal use of social media with task performance. He tests the effects with efficiency models and a well-being model (to test happiness). The results show that higher amounts of social media use lead to negative effects on both outputs, on efficiency, and on well-being. (Phu \& Gow, 2019) investigate the associations between Facebook use and happiness through loneliness and find both positive and negative associations. They find that a greater number of friends is positively associated with the user's well-being. On the other hand, an "emotional connectedness an individual has towards Facebook, was associated with higher levels of loneliness" (Phu \& Gow, 2019, p.151). On the contrary, the findings of (Błachnio, Przepiorka, \& Pantic, 2016) show that ordinary Facebook users differ in self-esteem and life satisfaction. They find that Facebook addiction negatively affects self-esteem and life satisfaction. A different approach is given by (Bozoglan, Demirer, \& Sahin, 2013) who test the influence of loneliness, self-esteem, and life satisfaction on internet addiction. They find that loneliness is the most influential factor in explaining the total variance in internet addiction. These studies show that in order to satisfy these needs, users may face depression and addiction dangers. In general, a large number of studies examine the negative effects of the pathological use on life satisfaction (for a list, see Duradoni, Innocenti, \& Guazzini, 2020). However, little is known about the mechanism that underlies the relation between addiction and the negative effects on an individual's behavior (Foroughi, Iranmanesh, Nikbin, \& Hyun, 2019).

On the contrary, there is another group of scholars who observe that the relation among the overuses of the internet, SNS, and gaming and the negative effects on an individual's behavior 
is insignificant (Ferguson \& Colwell, 2017; DeCamp \& Ferguson, 2017; Ferguson, 2017; Przybylski, 2014). For example, (Ferguson, 2017) does not find any correlation between children viewing television and computer games and having aggressive or violent behavior. (Przybylski, 2014) makes similar findings. His results show no such relation exists. (Chae, 2018) build an exploratory model to investigate the effects of different social media platforms (Blog, Community, Facebook Twitter, Instagram, LinkedIn, and Mobile messenger) on life satisfaction through an intermediate factor, but they are insignificant. (Phu \& Gow, 2019) support these findings and state that: "The literature to date has reported mixed results, which demonstrates the complexity and multidimensional nature of the usage of such sites" (p.158). Similarly, (Phu \& Gow, 2019) also state that: "The literature to date has reported mixed results, which demonstrates the complexity and multidimensional nature of the usage of such sites" (p.158). Similarly, in travel behavior research, social satisfaction has hardly received any attention from social network research (Weijs-Perrée, Van den Berg, Arentze, \& Kemperman, 2015). Yet, another line of research shows a positive association between SNS use and a positive outcome such as stress relief (Zhang, Kwok, Lowry, Liu, \& Wu, 2019).

This unagreeable environment makes our research highly important theoretically. Additionally, users are not always aware of how such applications or sites affect them and why such technologies are appealing to them (Punyanunt-Carter et al., 2017). Also, our findings have practical effects from which new legislation can be developed as well as new directions for parents to monitor their children.

Our research enriches traditional adoption models in information and communication technologies (ICT) such as the technology acceptance model or the theory of planned behavior when integrated and extended with models that study the adoption of SNS (Pedersen \& Ling, 2003). Furthermore, uses and gratifications (U\&G) has its basis in communication research, which integrates several disciplines (media and sociology) and focuses on mass media and mass communication. The general idea of this theory is individuals' understanding their gratification from technology use that is based on their needs or motivations (C. A. Lin, 1996). U\&G initiates the research with an exploratory start to end up with particular gratifications towards specific technology under research (Pedersen \& Ling, 2003). Thus, we explore gratification factors that individuals think they need when adopting social media apps. According to (Chan, $\mathrm{Wu}, \mathrm{Hao}$, $\mathrm{Xi}$, \& Jin, 2012), "Uses and gratifications theory provides a useful framework because it assumes that users are active in the choices of what communication channels to use to access particular content; that such choices are made based on the gratification of certain needs that can be obtained from the content". One feature in G\&U is its way of answering how to identify the gratifications that are used in the framework. According to (Pedersen \& Ling, 2003), "the researcher does not hypothesize which particular gratifications are sought by a particular technology. Instead, the individual subjects are either studied in a qualitative setting to explore possible gratifications, or a list of possible gratification assumed to be common for all media is presented to and rated by the subjects. These gratifications are mostly based upon early uses and gratifications studies."

Among the many types of media to address life satisfaction, entertainment use is the most important factor (Chan et al., 2012). This study considers other factors because they incorporate the most important needs that other studies address as gratifications from adopting SNS (BondsRaacke \& Raacke, 2010; Foroughi et al., 2019; Papacharissi \& Mendelson, 2010).

Therefore, by adopting U\&G theory, the first goal of this study is to explain the relation between pathological Snapchat use and depression and the life satisfaction of Snapchat users in Kuwait. Another goal is to investigate the significance of social and psychological factors that directly and indirectly affect the life satisfaction through pathological use and depression factors. 


\section{LITERATURE REVIEW}

\subsection{Life Satisfaction}

Many studies have investigated wellness and the quality of living standards (Duncan, 2010; Ngoo, Tey, \& Tan, 2015; Ott, 2013). These studies show that positive wellness can be grouped into two distinctive components: emotional and cognitive. The emotional component comprises positive indicators and the disappearance of negative effects (Ott, 2013); the cognitive component reflects the perceived quality and high level of satisfaction with one's life (Duncan, 2010).

Accordingly, studies define life satisfaction in different ways. For example, (Sumner, 1996) states: "A positive evaluation of the conditions of your life, a judgment that at least on balance, it measures up favorably against your standards or expectations". While (Neugarten, Havighurst, \& Tobin, 1961) define life satisfaction as "operational definition of successful aging". (Prasoon \& Chaturvedi, 2016) observe: "Life satisfaction is an overall assessment of feelings and attitudes about one's life at a particular point in time ranging from negative to positive". Based on the description of Shin \& Johnson (1978, p. 479) life satisfaction is "a global assessment of a person's quality of life according to his chosen criteria". These definitions clearly declare that life satisfaction is feeling positive about one's life. Therefore, ( Diener, Suh, Lucas, \& Smith, 1999) conclude that life satisfaction is one of three major indicators of wellness: life satisfaction and positive and negative effects. Furthermore, Choi et al. (2019) summarize the broad concept of life satisfaction as the sum of adjustment, leisure, happiness, health, and quality of life.

According to previous studies and discussions, the effect of life satisfaction touches almost all aspects of a person's life. For example, life satisfaction has an influence on health (Lombardo, Jones, Wang, Shen, \& Goldner, 2018; Zullig \& White, 2011), well-being (Ivanova, 2020; Kim \& Shen, 2020), marriage (Baryła-Matejczuk, Skvarciany, Cwynar, Poleszak, \& Cwynar, 2020; Plopa, 2020), income (Baryła-Matejczuk et al., 2020), occupational success (Zhao, Zhang, Liu, Ji, \& Lew, 2020), academic achievement (Warda, 2020), and so forth.

Different studies show that Social Networking Sites (SNS) overuse negatively influences life satisfaction. For example, social health factors, such as a dissatisfied marriage (Abbasi, Drouin, McDaniel, \& Dibble, 2019), loneliness (S. Lin, Liu, Niu, \& Longobardi, 2020; Ponnusamy, Iranmanesh, \& Foroughi, 2020), unemployment (Vancea, Shore, \& Utzet, 2019), and shyness (S. Lin et al., 2020) can all negatively influence life satisfaction. An important point here is that although many scholars have studied the negative effects of SNS overuse, little is known about the mechanism that underlies this relation (Foroughi et al., 2019). Previous studies show that pathological SNS use may lead to depression and negative effects on life satisfaction and well-being. However, the literature still lacks a full understanding of whether pathological use has a negative effect on life satisfaction. For example, a group of studies propose that social media can positively affect well-being (Ellison, Steinfield, \& Lampe, 2007; Tosun \& Lajunen, 2009), while another group of studies claim the opposite that such a relation is negative and detrimental (Brooks, 2015; Denti et al., 2012). The demand for studies on the relation among pathological use, depression, and life satisfaction such as ours is high. According to (Brooks, 2015), "understanding effects to both sides of a person's life is important for gaining a holistic picture of the individual". From a practical viewpoint, understanding such a relation enhances our ability as a society to maintain surveillance through a system of legislations and parental guidance.

\subsection{Pathological Snapchat Use and Depression}

The findings of many studies show that there is an association between becoming addicted to the internet and increased levels of depression (Özdemir et al., 2014; Young, 2004; Griffiths et 
al., 1999; Young \& Rodgers, 1998). Also, another group of studies expose the relation between excessive use of smartphones and depression (Cheever et al., 2018; Capon et al., 2016).

Although many studies have related new technologies to depression, still more research is needed according to (Wang et al., 2019). They think that there is a need to uncover the deep effects of online and smartphone uses such as gaming and social media apps.

The literature intensively investigates the excessive and overuse of Facebook. Thus, compared to Facebook, very few research studies investigate pathological Snapchat use. One important reason for this is the huge gap in the number of users worldwide between the two social media sites. However, Snapchat in this part of the world has a respectful share of the market for social media apps (Saquib, 2020).

We can still make use of plenty of studies that prove pathological SNS use since many similarities exist between other sites and apps and Snapchat (Kuss \& Griffiths, 2017). Furthermore, (Andreassen \& Pallesen, 2013; Balcerowska et al., 2020; Elphinston \& Noller, 2011; Mingchuan et al., 2020) argue that all social media is a subcategory of internet addiction and has a damaging effect on people's lives. Many studies show that addiction to technologies can lead to many problems (Blackwell, Leaman, Tramposch, Osborne, \& Liss, 2017) such as depression (Foroughi et al., 2019; Longstreet et al., 2018; Strulik, 2019) and loneliness (J. yeon Lee, Ko, \& Lee, 2019).

At the same time, many research studies have investigated factors that affect pathological internet use. Based on the U\&G, people do not use tools unless they have a goal since they are goal-oriented beings. An important issue in their goals is to meet their psychological and social needs (Pornsakulvanich, Haridakis, \& Rubin, 2008). The U\&G theory identifies important factors behind the use of social media. For example, (Papacharissi \& Mendelson, 2010) explain that there are nine factors behind using social media: habit, escapism, relaxation, inform, social interaction, professional goals, fun, friendship, and new knowledge. Similarly, another study (Bonds-Raacke \& Raacke, 2010) uses the U\&G theory to investigate reasons behind participants' use of Facebook and MySpace. They find that the justifications of such uses are to exchange pictures, socialization, new friendships, and to renew old ones.

One important reason for conducting our research is the reciprocal effect found in literature between pathological use and life satisfaction. While scholars study the impact of life satisfaction on Internet pathological use (Bozoglan et al., 2013), yet another group of scholars investigated the influence is made by Internet pathological use on life satisfaction (Shahnaz \& Karim, 2014).

(Punyanunt-Carter et al., 2017) investigate the relation between Snapchat use and addiction, needs, and satisfaction. They find that Snapchat influences all three factors. This is not true for (Donnelly \& Kuss, 2017) who demonstrate that there is a significant relation between Instagram use and the two dependent factors of addiction and depression. On the other hand, they find no statistically significant association between Facebook, Twitter, and Snapchat and the two behavioral factors of addiction and depression. Depending on this association, (Kuss, Shorter, van Rooij, Griffiths, \& Schoenmakers, 2014) identify the following six definitive features that are linked to SNS addiction: 1) salience, (2) mood modification, (3) tolerance, (4) withdrawal symptoms, (5) conflict, and (6) relapse (Kuss et al., 2014).

However, there is another school of thought on the internet and social media that argues that pathological use is not a real result of internet overuse. In terms of the social-cognitive theory (Bandura, 1986), there is more of a need for a comprehensive understanding of an individual's cognation, thinking, and behavior than what classical learning theory suggests. "According to (Bandura, 1991), the self-regulatory mechanism that determines an individual's level of self-control over behavior could also be relevant to internet addiction" (Özdemir, Kuzucu, \& Ak, 2014, p. 285). This mechanism means that self-control helps individuals to 
monitor themselves and their environment. This monitoring leads (Davis, 2001) to the conclusion that increased self-control is one aspect that is needed to overcome pathological use. Accordingly, (Caplan, 2010) updates his cognitive-behavioral theory by proposing that selfregulation is a critical factor in pathological internet use. In other terms, people with high levels of self-control and not sensation-seeking are more safe from developing a pathological symptom (Slater, 2003). Individuals with high levels of self-control are characterized more as focusing on long-term strategies instead of immediate gratifications (Baumeister \& Heatherton, 1996). Furthermore, people with high self-control can overcome stressful events and can be more tolerant of negative stimuli or emotions (Schmeichel \& Zell, 2007; Tangney, Boone, \& Baumeister, 2004). In general, a high level of self-control is associated with fewer disorders and better control of and coping with negative thoughts and more successful achievement of positive behaviors (Heatherton, 2011; Hofmann, Friese, \& Strack, 2009). According to (Ferguson \& Colwell, 2017), "scholarly consensus on media effects continues to prove difficult to achieve". (DeCamp \& Ferguson, 2017; Ferguson, 2017) find no negative effects from television and computer games on child behavior, which also is similar to the findings of (Przybylski, 2014) who observe that the relation between video games and behavioral outcomes is insignificant.

(Kuss \& Griffiths, 2011) review the literature and collected references to provide "empirical and conceptual insight into the emerging phenomenon of addiction to SNSs by: (1) outlining SNS usage patterns, (2) examining motivations for SNS usage, (3) examining personalities of SNS users, (4) examining negative consequences of SNS usage, (5) exploring potential SNS addiction, and (6) exploring SNS addiction specificity and comorbidity" (p. 3528). The same group in another research study lists 10 lessons the scientific community has learned from publications during the previous decade about SNS addiction (Kuss \& Griffiths, 2017).

Finally, according to (Caci, Cardaci, Scrima, \& Tabacchi, 2017), social media impair individual's daily activities (family, work, and other social life activities). Although this claim is well respected in the literature, one major criticism is that not enough studies adopted in the Middle East explain the effects of other social medias such as Snapchat. Those social media that have been developed and introduced lately to the market such as Snapchat (founded in 2011 by Evan Spiegel) have not been studied comprehensively and, hence, the picture is still not clear how negative the effects of SNS are.

\subsection{Social and Psychosocial Factors}

Previous studies have supported the claim that pathological SNS use has its roots in social and psychological needs (Albarashdi, 2020; Alhabash, Chiang, \& Huang, 2014; J. Balakrishnan \& Griffiths, 2018; V. Balakrishnan \& Shamim, 2013; Balcerowska et al., 2020; Masur et al., 2014). For example, (V. Balakrishnan \& Shamim, 2013) find that the psychological benefits from socialization, entertainment, and self-presentation lead to intensive use and pathological SNS use. Similarly, (Chan et al., 2012) find the needs for recognition, information, socialization, and entertainment lead to pathological SNS use. In addition, the fear of a negative evaluation by others is a key proposition of cognitive-behavioral models. These models consider the fear of a negative evaluation as an influential factor in social anxiety (Clark \& Wells, 1995; Weeks et al., 2005). Weeks et al. (2005) argue that this fear "consists of feelings of apprehension about others' evaluations, distress over these negative evaluations, and the expectation that others will evaluate one negatively" [p.179]. (Inderbitzen-Nolan \& Walters, 2000) introduce the fear of a negative evaluation as an important factor that forces people to stay with their SNS account instead of face-to-face contacts, which can also lead to extensive use. This finding is confirmed by (Casale, Rugai, \& Fioravanti, 2018) who find that the effect of the fear of a negative evaluation is statistically significant for problematic SNS use. 
Furthermore, the privacy calculus theory (Laufer \& Wolfe, 1977) assumes that people are mature and refuse to disclose their information unless their privacy is positively secured (Dinev \& Hart, 2006). Information privacy is defined as "the ability of individuals to control when, how, and to what extent their personal information is accessed" (Pentina, Zhang, Bata, \& Chen, 2016; Smith, Milberg, \& Burke, 1996). Different studies show the importance of privacy as a factor that determines life satisfaction in many topics such as politics (Böhnke, 2008), social environment, (Carmon, Miller, \& Brasher, 2013), medical environment (Nayeri \& Aghajani, 2010), and psychological atmosphere (Jørgensen, Thygesen, Andersen, Due, \& Michelsen, 2020; Leversen, Danielsen, Birkeland, \& Samdal, 2012). However, there is lack of research that measures the effects of privacy on life satisfaction in general and in particular on the elderly (Kim \& Shen, 2020).

In the relation between privacy and pathological use, researchers have examined the relation between the two. This line of research studies investigates the influence of online pathological use on levels of personal and sensitive data disclosure. Yet, another group of studies investigates the opposite by testing the effect of levels of personal data on the pathological addiction to the new technology. For example, (Acquisti, 2004; Sanders et al., 2010) examine the effect of online gaming addiction on personal data disclosure. On the contrary, a group of studies show the opposite is also true (Błachnio, Przepiorka, Boruch, \& Bałakier, 2016). According to (Błachnio, Przepiorka, Boruch, et al., 2016), "there is a relation between privacy value and selfdisclosure". Their findings indicate that privacy is a negative predictor of Facebook use, which is also indicated by (Zlatolas et al., 2015). According to (Stieger, Burger, Bohn, \& Voracek, 2013), people who are really concerned about keeping their personal information away from foreigners and who highly value their privacy quit SNS more often.

An important point to make in this regard is that the research has investigated and verified privacy in several fields and cases. However, it has limited applications in the field of social media (Pentina et al., 2016). As we mentioned previously, many research studies investigate the association between privacy and pathological use (Acquisti, 2004; Sanders et al., 2010) but very few examine the influence of keeping the information private on the type of users' habits of use. In addition, many scholars have explored the relation between privacy attitudes and behavior but yet this relation is not fully explained according to Acquisti (2004). We argue that SNS companies do not declare this point clearly in their policies and business strategies. Therefore, in our study we hypothesize that people who value their privacy are not willing to disclose their personal information which reflects negatively on the degree of Snapchat use.

On the other hand, social phobia or social anxiety disorder have attracted too much attention in recent years. This problematic issue is studied intensively, and the findings show an important association between the social anxiety disorder and impairment, since it interferes with social and personal normal development. This impairment is reflected in school avoidance, job problematic issues, and social avoidance. This is why many phobic people report experiencing serious levels of depression and suicide attempts (Francis, Last, \& Strauss, 1992) and substance abuse (Inderbitzen-Nolan \& Walters, 2000). Fear of a negative evaluation affects addiction, depression (M. S. Lee, Oh, Cho, Hong, M. J., \& Moon, 2001), and life satisfaction in general.

The fear of a negative evaluation is a characteristic feature of social anxiety disorders (Rapee \& Heimberg, 1997) that many studies find affects internet addiction (Buyukbayraktar, 2020; Casale et al., 2018; Wolniewicz, Tiamiyu, Weeks, \& Elhai, 2018). We hypothesizes that individuals who feel anxious try to avoid face-to-face communication and prefer, instead, to communicate through electronic means and SNS (Buyukbayraktar, 2020). What is interesting at this point is that some argue that individuals with social anxiety may even have difficulty in recognizing the feelings of others (O'Toole, Hougaard, \& Mennin, 2013). For this reason, we 
want to identify the direct relation of the fear of a negative evaluation on pathological Snapchat use.

Following (Chan, Wu, Hao, Xi, \& Jin, 2012; Foroughi et al., 2019), our research adopts privacy, entertainment, social, fear, and recognition as motivators for Snapchat use. These needs are adopted because many studies deem them to be significant, such as (Bonds-Raacke \& Raacke, 2010; Hong \& Thong, 2013; Papacharissi \& Mendelson, 2010; Stieger et al., 2013).

Based on this discussion, we propose the following hypotheses followed by Figure 1 that shows the research model of this study.

H1: Perceived privacy influences life satisfaction.

H2: Perceived privacy influences pathological Snapchat use.

H3: Entertainment needs influence pathological Snapchat use.

H4: Social needs influence pathological Snapchat use.

H5: Social needs influence life satisfaction.

H6: Fear of negative evaluation influences pathological Snapchat use.

H7 $:$ : Fear of negative evaluation influences depression.

H8: Fear of negative evaluation influences life satisfaction.

H9: Recognition needs influence pathological Snapchat use.

H10: Pathological Snapchat use influences depression.

H11: Pathological Snapchat use influences life satisfaction.

H12: Depression influences life satisfaction.

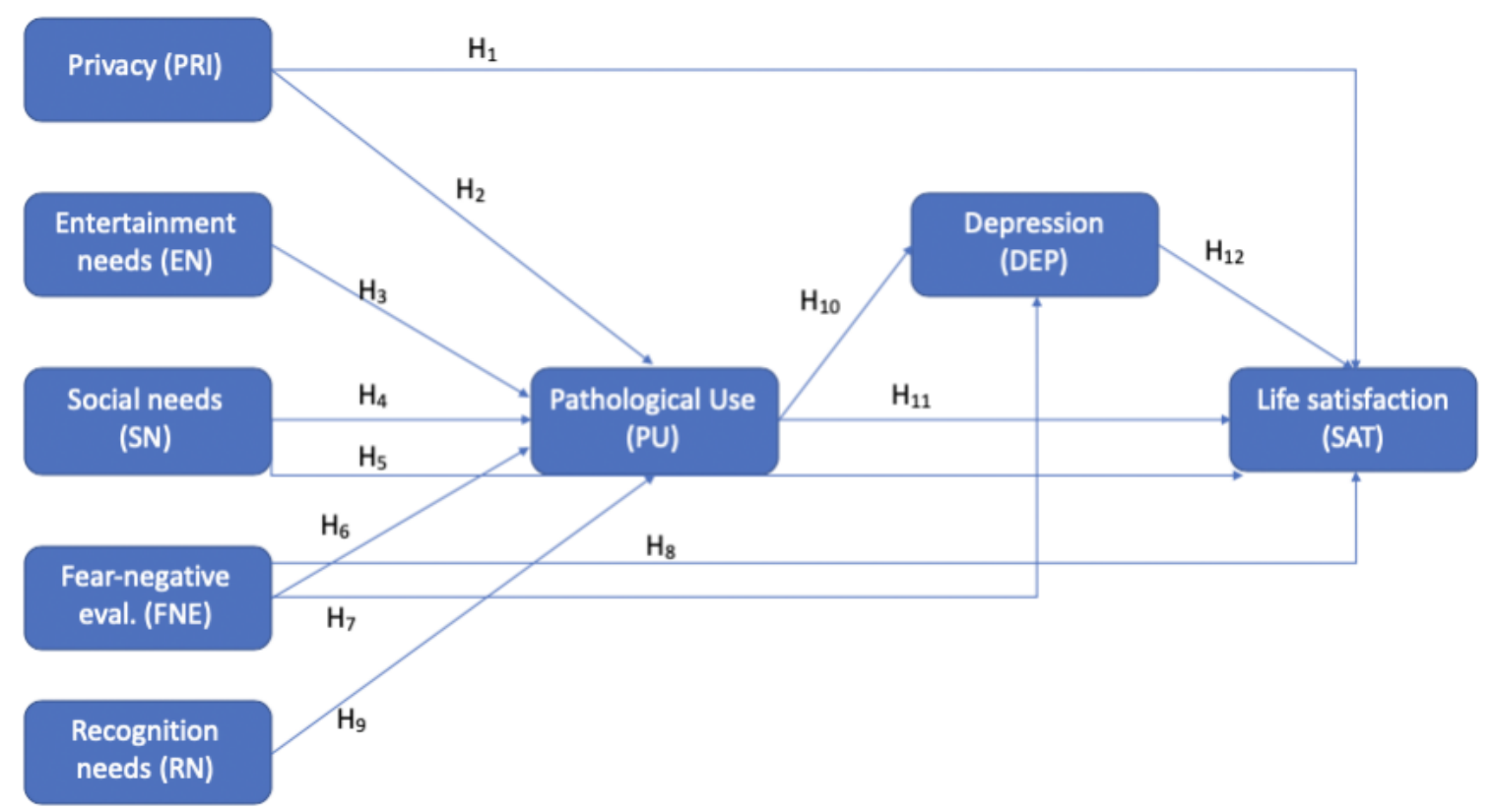

Figure 1 The research model

\section{RESEARCH METHOD, POPULATION, AND DATA ANALYSIS}

\subsection{Sampling and Data Collection}

The focus of this study is Snapchat users in Kuwait that makes our sample study representative to all sectors. Thus, we construct a questionnaire based on the research model to collect opinions about the participants type of Snapchat use. As a first step, we asked two information system professors in the College of Business Administration at Kuwait University to review the 
questionnaire. We asked these two professors to translate the instrument items into Arabic, since the study used mostly Arab participants. Then, we asked one translator to translate the Arabic version back into English to compare it with the original items to double check the correctness of the two versions (original and translated).

Once both translations were done, we distributed the instrument to over 30 students in a management information systems (MIS) introductory course as a pilot study to identify any unclear items. After distribution, we gave one full lecture to explain what the purpose of the study was and gave a detailed description of the instrument items. After minor comments on the original survey, we assigned the task of distributing the questionnaire to two of these students who would be compensated with 5 points added to their class grades. Thus, the students randomly distributed the instrument to their friends and family members who use Snapchat regardless of their age or academic background. Table 1 shows the demographics of the participants.

Table 1 Demographical data on participants

\begin{tabular}{|c|c|c|c|c|}
\hline Variable & Category & Sectors & Frequency & Percent \\
\hline \multirow[t]{9}{*}{ Age } & 1 & Less than 15 & 7 & 1.6 \\
\hline & 2 & $15<20$ & 70 & 16.3 \\
\hline & 3 & $20<25$ & 147 & 34.2 \\
\hline & 4 & $25<30$ & 35 & 8.1 \\
\hline & 5 & $30<35$ & 38 & 8.8 \\
\hline & 6 & $35<40$ & 37 & 8.6 \\
\hline & 7 & $40<45$ & 47 & 10.9 \\
\hline & 8 & $45<50$ & 34 & 7.9 \\
\hline & 9 & 50 and above & 15 & 3.5 \\
\hline \multirow[t]{3}{*}{ Gender } & 0 & Not declared & 8 & 1.9 \\
\hline & 1 & Male & 100 & 23.3 \\
\hline & 2 & Female & 322 & 74.9 \\
\hline \multirow[t]{5}{*}{ Academic Background } & 0 & Not declared & 1 & .2 \\
\hline & 1 & $\begin{array}{l}\text { High School or } \\
\text { less }\end{array}$ & 64 & 14.9 \\
\hline & 2 & 2 years college & 64 & 14.9 \\
\hline & 3 & 4 years college & 277 & 64.4 \\
\hline & 4 & MS/PHD & 24 & 5.6 \\
\hline \multirow[t]{5}{*}{ Social status } & 0 & Not declared & 1 & .2 \\
\hline & 1 & Single & 232 & 54.0 \\
\hline & 2 & Married & 177 & 41.2 \\
\hline & 3 & Separate & 17 & 4.0 \\
\hline & 4 & Widow & 3 & .7 \\
\hline \multirow[t]{3}{*}{ Religion } & 0 & Not declared & 2 & .5 \\
\hline & 1 & Muslim & 425 & 98.8 \\
\hline & 2 & Non-Muslim & 3 & .7 \\
\hline \multirow[t]{7}{*}{ Monthly income } & 0 & Not declared & 4 & .9 \\
\hline & 1 & 500 or less & 186 & 43.3 \\
\hline & 2 & $500<1000$ & 66 & 15.3 \\
\hline & 3 & $1000<1500$ & 71 & 16.5 \\
\hline & 4 & $1500<2000$ & 49 & 11.4 \\
\hline & 5 & $2000<2500$ & 29 & 6.7 \\
\hline & 6 & 2500 and more & 25 & 5.8 \\
\hline
\end{tabular}


The sample consisted of 430 participants of which approximately $74.9 \%$ were female (322) and $23.3 \%$ were male (100). The majority of the participants, $64.4 \%(277)$, had a BS college degree, 5.6\% (24) had MS/PhD degrees, and 29.8\% (128) had either 2-year diploma or less. Participants' ages ranged from 15 to more than 50 (categories: $\mathrm{M}=5.37, \mathrm{SD}=2.166$ ).

\subsection{Research Instrument}

The questionnaire divided into two parts. The first part collected the respondent's personal data. The second part focused on the research model and comprised following parts: The independent factors are the needs for recognition ( 5 items), socialization ( 5 items), and entertainment ( 5 items) and come from (Chan et al., 2012). The fear of a negative evaluation ( 8 items) comes from (Hussain, Williams, \& Griffiths, 2015), and the perceived privacy items (6 items) come from (Hong \& Thong, 2013).

The items for the pathological Snapchat use are recycled from (Hussain et al., 2015). Further, I use 20-items for depression from (Radloff, 1977), and the life satisfaction items comes from (Diener, Emmons, \& Griffin, 1985). The questions on the research constructs were assessed using five-point Likert scale ( $1=$ "Strongly agree" to $5=$ Strongly disagree").

\section{STATISTICAL ANALYSIS}

To get excellent results, we used many tools in the statistical analysis to check for the validity and dependency of the instrument. We carried out a factor analysis before any other analysis because of its validity in removing any redundancy that might exist between the study items (Abbas \& Hamdy, 2015). Table 2 shows the factor loadings of the study measurements.

Table 2 Factor analysis, variance, and Cronbach $\alpha$ reliability.

\begin{tabular}{|c|c|c|c|c|}
\hline Latent Var & Items & $\begin{array}{l}\text { Factor } \\
\text { Loadings }\end{array}$ & Variance & $\begin{array}{c}\text { Cronbach } \\
\alpha \\
\text { Reliability }\end{array}$ \\
\hline \multirow[t]{4}{*}{ Life Satisfaction } & & & $80.022 \%$ & $87.5 \%$ \\
\hline & $\mathrm{SAT}_{2}$ & .900 & & \\
\hline & $\mathrm{SAT}_{3}$ & .898 & & \\
\hline & $\mathrm{SAT}_{4}$ & .862 & & \\
\hline \multirow[t]{4}{*}{ Privacy } & & & $83.69 \%$ & $90.3 \%$ \\
\hline & $\mathrm{PR}_{2}$ & .911 & & \\
\hline & $\mathrm{PR}_{3}$ & .923 & & \\
\hline & $\mathrm{PR}_{4}$ & .899 & & \\
\hline \multirow[t]{4}{*}{ Recognition Needs } & & & $76.06 \%$ & $84.2 \%$ \\
\hline & $\mathrm{RN}_{1}$ & .834 & & \\
\hline & $\mathrm{RN}_{2}$ & .883 & & \\
\hline & $\mathrm{RN}_{3}$ & .841 & & \\
\hline \multirow[t]{3}{*}{ Entertainment Needs } & & & $90.5 \%$ & $91.31 \%$ \\
\hline & $\mathrm{EN}_{3}$ & .917 & & \\
\hline & $\mathrm{EN}_{4}$ & .917 & & \\
\hline \multirow[t]{3}{*}{ Social needs } & & & $80.1 \%$ & $83.6 \%$ \\
\hline & $\mathrm{SR}_{1}$ & .893 & & \\
\hline & $\mathrm{SR}_{2}$ & 889 & & \\
\hline \multirow[t]{4}{*}{ Pathological use } & & & $88.2 \%$ & $80.86 \%$ \\
\hline & $\mathrm{PU}_{3}$ & .875 & & \\
\hline & $\mathrm{PU}_{4}$ & .859 & & \\
\hline & $\mathrm{PU}_{5}$ & .879 & & \\
\hline
\end{tabular}




\begin{tabular}{|l|l|c|c|c|}
\hline $\begin{array}{l}\text { Fear of Negative } \\
\text { Eval. }\end{array}$ & & & $\mathbf{9 1 . 1 \%}$ & $\mathbf{8 4 . 9 \%}$ \\
\hline & $\mathrm{FNE}_{1}$ & .891 & & \\
\hline & $\mathrm{FNE}_{2}$ & .918 & & \\
\hline & $\mathrm{FNE}_{3}$ & .872 & & \\
\hline Depression & & & $\mathbf{8 8 . 1 \%}$ & $\mathbf{8 0 . 7 5 \%}$ \\
\hline & $\mathrm{DEP}_{6}$ & .854 & & \\
\hline & $\mathrm{DEP}_{14}$ & .882 & & \\
\hline & $\mathrm{DEP}_{18}$ & .876 & & \\
\hline Overall & & & $\mathbf{7 9 \%}$ & $\mathbf{8 2 . 7 8 \%}$ \\
\hline
\end{tabular}

Table 2 shows that many questions were removed due to lack of reliability and lack of explanation for the reasonable variance. Therefore, we kept only questions in Table 2 that passed the reliability tests. The principal component analysis with varimax rotation was used (eigenvalue greater than one and factor loadings greater than 0.5) (Kaiser, 1958). All variances in Table 2 are above $85 \%$, which are statistically acceptable according to (Hair, Black, Babin, Anderson, \& Tatham, 2010). Furthermore, Table 2 also shows two other important measurements; the reliabilities of all factors in the study are above $70 \%$ and all variances are above $60 \%$, which are acceptable thresholds according to (Hair et al., 2010).

\subsection{Fitness of Conceptual Model and Latent Constructs Validation}

We used Lisrel 8.54 software to test the fitness of the conceptual model using Structural Equation Modeling method (SEM). The results of the test are in Table 3. Table 3 clearly shows that the conceptual model is statistically satisfied and verified. Particularly, the RMR $=0.046$ (recommended 0.05 or less), GFI $=0.91$ (recommended 0.80 or more), and the AGFI $=0.88$ (recommended 0.80 or more).

Table 3 Goodness of fit statistics for research model

\begin{tabular}{|l|c|}
\hline \multicolumn{1}{|c|}{ Goodness of fit statistics } & Index \\
\hline Normed Fit Index (NFI) & 0.94 \\
\hline Non-Normed Fit Index (NNFI) & 0.95 \\
\hline Parsimony Normed Fit Index (PNFI) & 0.76 \\
\hline Comparative Fit Index (CFI) & 0.96 \\
\hline Incremental Fit Index (IFI) & 0.96 \\
\hline Relative Fit Index (RFI) & 0.92 \\
\hline Critical N (CN) & 214.43 \\
\hline Root Mean Square Residual (RMR) & 0.046 \\
\hline Standardized RMR & 0.046 \\
\hline Goodness of Fit Index (GFI) & 0.91 \\
\hline Adjusted Goodness of Fit Index (AGFI) & 0.88 \\
\hline Parsimony Goodness of Fit Index (PGFI) & 0.67 \\
\hline
\end{tabular}

More testing is needed after validating the conceptual model. The new test measures the reliability and validity of the latent constructs. The composite reliability and variance extracted tests can be calculated as follows:

$$
\begin{gathered}
\text { Composite reliability }=\frac{\left(\sum \text { Standardized loadings }\right)^{2}}{\left(\sum \text { Standardized loadings }\right)^{2}+\sum \mid \text { error } \mid} \\
\text { Variance extracted }=\frac{\sum(\text { Standardized loadings })^{2}}{\sum(\text { Standardized loadings })^{2}+\sum \mid \text { error } \mid}
\end{gathered}
$$


Life satisfaction as defined by Snapchat usage and addiction Case study in Kuwait

Table 4 Latent constructs reliability, variance, and R2

\begin{tabular}{|l|l|l|l|l|}
\hline & & $\begin{array}{l}\text { CCR } \\
(\text { Rec. }>\mathbf{5 0 \% )}\end{array}$ & $\begin{array}{l}\text { AVE } \\
(\text { Rec. }>\text { 70\%) }\end{array}$ & $\mathbf{R}^{\mathbf{2}}$ \\
\hline Satisfaction & SAT & 0.894379 & 0.739174 & 0.09 \\
\hline Privacy & PRI & 0.909293 & 0.769701 & --- \\
\hline Recognition needs & RN & 0.869567 & 0.690547 & --- \\
\hline Entertainment needs & EN & 0.935776 & 0.879306 & --- \\
\hline Social needs & SN & 0.848068 & 0.736213 & --- \\
\hline Pathological use & PU & 0.901333 & 0.752889 & 0.33 \\
\hline $\begin{array}{l}\text { Fear of negative } \\
\text { evaluation }\end{array}$ & FNE & 0.935223 & 0.828145 & --- \\
\hline Depression & DEP & 0.911106 & 0.774131 & 0.29 \\
\hline
\end{tabular}

Table 4 shows the results for the reliability and variance of the latent constructs. According to (Hair et al., 2010), 50\% or more for reliability and $70 \%$ or more for variance is recommended. Both tests are verified for the latent constructs.

Moreover, another measure for reliability is needed. In order to validate and emphasize the importance of the research model, I also carry out a discriminant validity (DV) test. This test is "to ensure there was no existence of overlapping among the study measurements. In other words, the questions that are used in the survey should not be overlapped where one question can measure two or more constructs. The discriminant validity test is acceptable as long as the result is less than or equal to 0.85 " (Abbas \& Hamdy, 2015). The DV is computed as follows:

$$
D V_{x y}=\frac{\operatorname{Corr}(x, y)}{\sqrt{r e l_{x} * r e l_{y}}}
$$

Table 5 Discriminant validity test for latent constructs of conceptual model

\begin{tabular}{|c|c|c|c|c|c|c|c|c|c|}
\hline & & SAT & PRI & $\mathrm{RN}$ & EN & $\mathrm{SN}$ & PU & FNE & DEP \\
\hline Satisfaction & SAT & 1 & & & & & & & \\
\hline Privacy & PRI & 0.155244 & 1 & & & & & & \\
\hline $\begin{array}{l}\text { Recognition } \\
\text { needs }\end{array}$ & $\mathrm{RN}$ & 0.045357 & 0.022492 & 1 & & & & & \\
\hline $\begin{array}{l}\text { Entertainment } \\
\text { needs }\end{array}$ & $\mathrm{EN}$ & 0.109308 & 0.086727 & 0.232799 & 1 & & & & \\
\hline Social needs & SN & 0.287054 & 0.216365 & 0.244541 & 0.381661 & 1 & & & \\
\hline $\begin{array}{l}\text { Pathological } \\
\text { use }\end{array}$ & $\mathrm{PU}$ & 0.066826 & 0.011046 & 0.395343 & 0.533541 & 0.240194 & 1 & & \\
\hline $\begin{array}{l}\text { Fear of } \\
\text { negative } \\
\text { evaluation }\end{array}$ & FNE & -0.0656 & 0 & -0.01109 & 0 & -0.01123 & 0.250511 & 1 & \\
\hline Depression & DEP & -0.15509 & 0 & 0.168521 & 0.01083 & 0 & 0.165525 & 0.584994 & 1 \\
\hline
\end{tabular}

Table 5 shows the results. They show that the DV is verified and statistically successful. "In meaningful terms, the results of this test show that the questionnaire is clear and does not suffer from overlapping and that each group of questions expresses and explains the relative latent construct accordingly" (Abbas \& Hamdy, 2015).

\subsection{Path Analysis}

Previous statistical tests and analysis have verified the research model and shown that it is statistically successful. At this stage, we are ready to compute and test the significance of the 
paths between the study constructs in the research model (Figure 1) (standardized path coefficients are used).

Table 6 Path analysis

\begin{tabular}{|l|c|l|l|l|l|c|}
\hline & Hypotheses & Sig. & \multicolumn{1}{c|}{$\mathrm{r}$} & $\mathrm{t}_{\text {value }}$ & $\mathrm{p}_{\text {value }}$ & Path coefficient $(\gamma)$ \\
\hline PRI->SAT & $\mathbf{H}_{\mathbf{1}}$ & Sig & $\mathbf{0 . 1 4}$ & $\mathbf{2 . 9 2 5 2}$ & $\mathbf{0 . 0 0 1 8 1 3}$ & $\mathbf{0 . 1 0}$ \\
\hline PRI->PU & $\mathrm{H}_{2}$ & Not & 0.01 & 0.2069 & 0.418096 & --- \\
\hline EN->PU & $\mathbf{H}_{\mathbf{3}}$ & Sig & $\mathbf{0 . 4 9}$ & $\mathbf{1 1 . 6 2 8 9}$ & $\mathbf{0 . 0 0 0 0 0 0}$ & $\mathbf{0 . 4 4}$ \\
\hline SN->PU & $\mathbf{H}_{4}$ & Sig & $\mathbf{0 . 2 1}$ & $\mathbf{4 . 4 4 3 6}$ & $\mathbf{0 . 0 0 0 0 0 6}$ & $\mathbf{0 . 0 4}$ \\
\hline SN->SAT & $\mathbf{H}_{\mathbf{5}}$ & Sig & $\mathbf{0 . 2 5}$ & $\mathbf{5 . 3 4 1 7}$ & $\mathbf{0 . 0 0 0 0 0 0}$ & $\mathbf{0 . 2 3}$ \\
\hline FNE->PU & $\mathbf{H}_{\mathbf{6}}$ & Sig & $\mathbf{0 . 2 3}$ & $\mathbf{4 . 8 8 9 4}$ & $\mathbf{0 . 0 0 0 0 0 1}$ & $\mathbf{0 . 1 7}$ \\
\hline FNE->DEP & $\mathbf{H}_{7}$ & Sig & $\mathbf{0 . 5 6}$ & $\mathbf{1 3 . 9 8 3 7}$ & $\mathbf{0 . 0 0 0 0 0 0}$ & $\mathbf{0 . 5 4}$ \\
\hline FNE-SAT & $\mathrm{H}_{8}$ & Not & -0.06 & -1.2435 & 0.892823 & --- \\
\hline RN->PU & $\mathbf{H}_{9}$ & Sig & $\mathbf{0 . 3 5}$ & $\mathbf{7 . 7 2 9 8}$ & $\mathbf{0 . 0 0 0 0 0 0}$ & $\mathbf{0 . 2 1}$ \\
\hline PU->DEP & $\mathbf{H}_{10}$ & Sig & $\mathbf{0 . 1 5}$ & $\mathbf{3 . 1 3 8 7}$ & $\mathbf{0 . 0 0 0 9 0 7}$ & $\mathbf{0 . 0 3}$ \\
\hline PU->SAT & $\mathrm{H}_{11}$ & Not & 0.06 & 1.2435 & 0.107177 & --- \\
\hline DEP->SAT & $\mathrm{H}_{12}$ & Not & -0.14 & -2.9252 & 0.998187 & --- \\
\hline
\end{tabular}

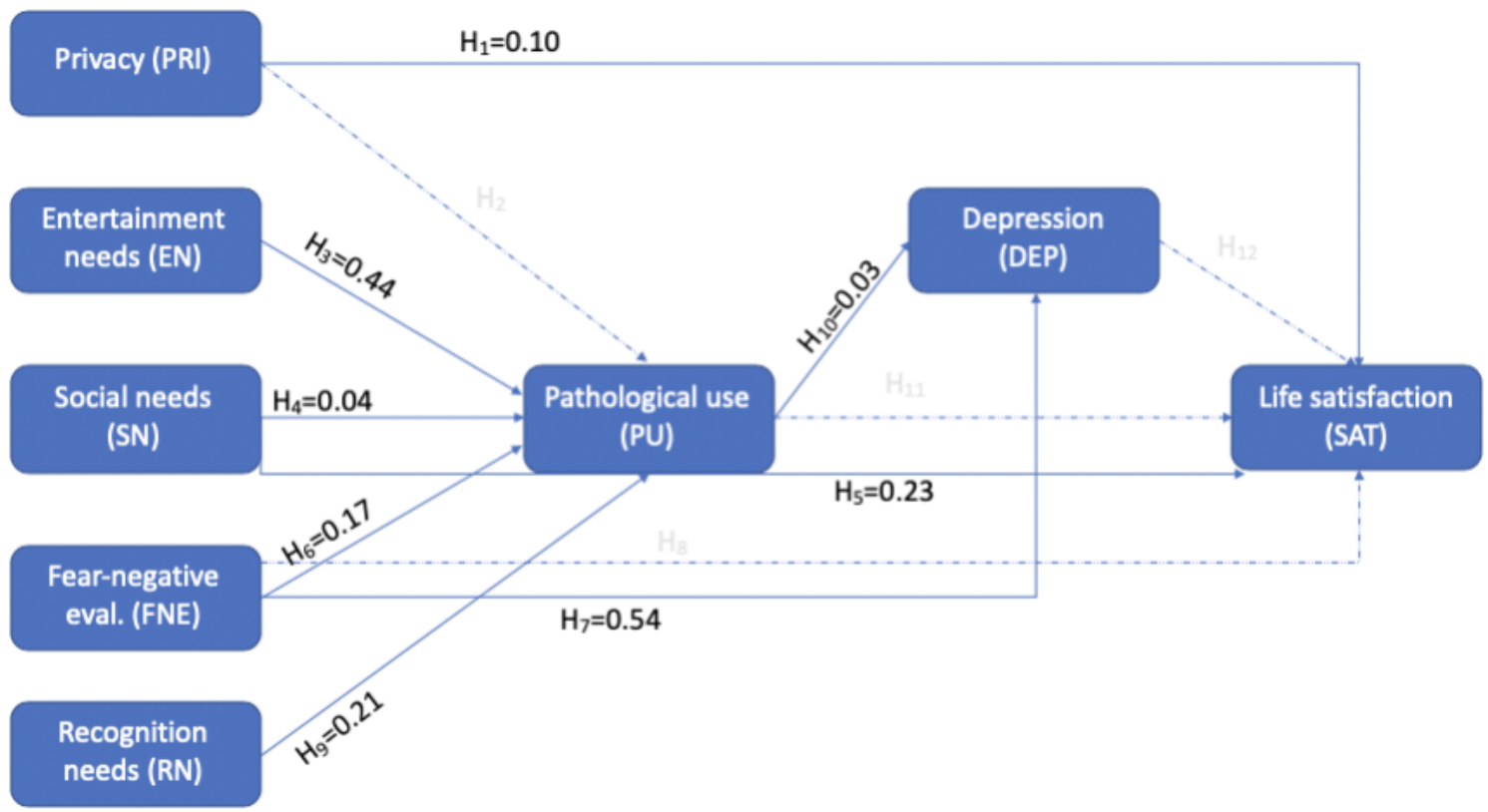

Figure 2 Research model with path coefficients.

\section{DISCUSSION}

In the Middle East, Snapchat is one of the most popular social media apps, and many age groups use it for various reasons. However, in the research environment, few studies exist on the pathological use of Snapchat. Also, no research studies investigate the life satisfaction of people in the Middle East and whether social media addiction and depression are playing a role. The aim of this research is to understand how the needs for privacy, entertainment, socialization, and recognition as well as the fear of a negative evaluation are associated with pathological Snapchat use. Also, this study examines the association among pathological Snapchat use, depression, and life satisfaction.

The results show that most of our hypotheses are verified. In addition, our findings also verify the findings of previous studies. The most influential effects are the fear of a negative 
evaluation and depression $(\gamma=0.54)$, followed by effect of entertainment needs $(\gamma=0.44)$ on pathological use. Among the factors that affect pathological use, our study verifies the results of (Chen, 2017; Foroughi et al., 2019) who find that entertainment needs are the most influential factor in pathological use. The results show that users of Snapchat heavily use it to satisfy their entertainment needs. This use means that such gratification will gradually develop into an irresistible habit that will eventually turn into intensive use.

An important comment to make here is that Kuwait is one country in the Gulf Countries Cooperation (GCC) in which socialization is considered an important way of life, and people gather almost on a daily basis. In Kuwait, people have one distinct social habit called Diwania. Diwania is a well-known place where family, friends, and neighbors (all mainly males) can sit and talk on many subjects, such as sports, politics, social life, and so forth, till the late hours of night. Social needs reflect being known socially by others in the society. This need includes exposing emotions and feelings; and sharing views, thoughts, and experiences to keep in touch with people. Those items are important components of socialization and a critical part of the Kuwaiti cultural personality. For this reason, we argue that it plays a significant role in the life satisfaction of Kuwaiti individuals. Accordingly, our findings show that the most influential effect on life satisfaction is social needs $(\gamma=0.23)$.

Another interesting point to make is that our results indicate that privacy does not affect pathological use. Thus, Kuwaiti Snapchat users do not care much about how often they disclose their personal information to the SNS company. This finding is in contrast to other studies that show such relation is statistically significant especially in the case of Facebook (Błachnio, Przepiorka, Boruch et al., 2016; Stieger et al., 2013; Zlatolas et al., 2015). It is possible that most users are teenagers who do not understand the complications of such dangerous issues. Another probable reason is that they are unaware of the technical side of it, which makes them naïve to their level of recklessness with their privacy.

An important comment regarding depression. It is clear people who are highly sensitive and fear being criticized by others (Inderbitzen-Nolan \& Walters, 2000) aim to use SNS and in particular Snapchat and are in danger of becoming depressed by such evaluations. Therefore, the effect of the fear of negative evaluation is the most influential on depression $(\gamma=0.54)$. Thus, what we find is that fear of a negative evaluation is significant to Kuwaiti Snapchat users and affects the degree of pathological Snapchat use and the degree of depression, but not their life satisfaction. On the contrary, (Casale et al., 2018) find no association between the fear of a negative evaluation and the problematic use of social media. However, the result is harmonious with other studies in which the fear of a negative evaluation is associated with a degree of depression (Inderbitzen-Nolan \& Walters, 2000; M. S. Lee et al., 2001).

One last comment regards the negative output of our research study. Our findings show that pathological Snapchat use has no statistical significance on life satisfaction nor a direct or indirect association with depression. This association confirms the findings of other scholars who have examined the associations between technologies (TV, gaming, SNS, etc.) and negative output (Ferguson \& Colwell, 2017; DeCamp \& Ferguson, 2017; Ferguson, 2017; Przybylski, 2014).

\section{CONCLUSION, IMPLICATIONS, AND LIMITATIONS}

Our aim in this study is to investigate the factors that affect an individual's life satisfaction in Kuwait. We have found that social needs is the most influential factor $(\gamma=0.23)$ followed by privacy $(\gamma=0.10)$. Furthermore, all independent factors (hypotheses) carry significant effects on pathological Snapchat use. Although Snapchat users feel many reasons for gratification, the entertainment need is the most influential factor for pathological use $(\gamma=0.44)$. 
Our findings contribute to the current body of knowledge by introducing theoretical and practical support. Regarding the theoretical contribution, the major contribution of this study is the role of entertainment in the use of such apps. Another contribution is practical where SNS developers in general and Snapchat in particular are encouraged to develop more entertainment features in their apps, like new updates on filters and stickers.

This study finds that the hypothesis that people who are sensitive to their information privacy normally quit or reduce their level of Snapchat or SNS use in general (Zlatolas et al., 2015 ) is not valid, which means people in Kuwait do not see any relation between the two. This finding may be true for different reasons. First, most people have no idea, or do not think, that Snapchat may sell their personal information to third parties. Second, the probability is that most users are in their twenties or less, so their lack of experience leads them to misjudge the degree of seriousness and danger in the matter. Consequently, they disrespect this critical personality trait and lean more toward the fun and enjoyment of playing with Snapchat's features. Yet, another probable reason for this disrespect is that people are aware of privacy, but they are unaware of the technical side of it, which makes them naïve to their level of recklessness with their privacy. Finally, according to the privacy calculus theory, it is probable that people calculate their benefits and costs of disclosing their personal information and find that the benefits outweigh the costs.

Moreover, pathological use has many dangerous complications if not controlled for. Our results show all external factors have significant associations with pathological Snapchat use. This is why we think all such gratifications and many others lead the majority of users into danger such as avoiding socialization, work performance related problems, class work failure, and so forth. In addition, social needs have a powerful association with life satisfaction. This association means Kuwaiti people can indeed be categorized as in the socialization dimension of (Hofstede, 2014). This categorization means social media play a positive role in enhancing social relations between Kuwaiti individuals and the community they live in.

Finally, although many studies show significant associations between pathological use and negative behavioral and social results, many other studies show no such importance. This finding may lead to a further need to explore this relation and to identify which factors may be effective intermediaries between the two.

There are many implications to this study. The first implication is for businesses. Since most users seek Snapchat for entertainment, it could be the perfect medium for marketing and promotions. Another implication can be directed at the parents of youngsters. The correlation between age and pathological use is significant $(\mathrm{r}=-0.176$ and sig. $=0.000)$ and that means parents have an obligation to keep their children's SNS app use at healthy limits. Another implication is that privacy is not so much important in influencing the type of use but it makes a difference in life satisfaction. Yet another implication is to encourage people to pay more attention to privacy issues. The lack of this attention may be because people normally do not read the legal statements that such platforms issue because it is lengthy and contains plenty of legal jargon that make it too complicated to read. However, still users need to give their privacy close attention. Another implication is to encourage SNS platforms to simplify their policy statements in order to make them readable for average users. Finally, social commerce is a term used to refer to e-commerce through social media that is an emerging trend where sellers are connected to their consumers through social media platforms. "The full potential of social commerce has not yet been reached. Those firms that are trying to tap into it may utilize the five manageable factors of addiction of SNS in establishing their strategies for SNS-based social commerce" (Kang, Shin, \& Park, 2013).

An important point to make at this point is that our study has many limitations. The first limitation is that the sample is homogenous. This means our participants are the Kuwaiti 
population where the majority are Kuwaiti nationality. This population makes the data more latent towards one side and not fully representative of other nationalities. The second limitation is not considering other important factors that influence pathological use and life satisfaction. For example, information needs (Foroughi et al., 2019), social anxiety (de Bérail, Guillon, \& Bungener, 2019), extraversion, neuroticism, and the fear of missing out (Blackwell et al., 2017) are among the other important factors that influence pathological use and life satisfaction.

Another limitation is that our study examines Snapchat use and life satisfaction. Our study shows no significant association between the two constructs. However, we cannot conclude that SNS has an insignificant association with negative behavioral uses because the audience of each type of social media differs significantly. For example, Snapchat users are mostly millennials and net generations. At the same time, the type of uses differs from one society to another. These demographical differences make such conclusions need to be more investigated. Yet another limitation is related to the U\&G framework, which we referred to previously. According to (Pedersen \& Ling, 2003), "the researcher does not hypothesize which particular gratifications are sought by a particular technology. Instead, the individual subjects are either studied in a qualitative setting to explore possible gratifications, or a list of possible gratification assumed to be common for all media is presented to and rated by the subjects. These gratifications are mostly based upon early uses and gratifications studies." This promotes choosing gratifications selective instead of using standard factors to be applied in any new experimental study.

\section{REFERENCES}

[1] Abbas, H. A., \& Hamdy, H. I. (2015). Determinants of continuance intention factor in Kuwait communication market: Case study of Zain-Kuwait. Computers in Human Behavior, 49, 648657. https://doi.org/10.1016/j.chb.2015.03.035

[2] Abbasi, I. S., Drouin, M., McDaniel, B. T., \& Dibble, J. L. (2019). The Protective Influence of Relationship Commitment on the Effects of Facebook Addiction on Marital Disaffection. American Journal of Family Therapy, 47(2), 120-136. https://doi.org/10.1080/01926187.2019.1613940

[3] Acquisti, A. (2004). Privacy in electronic commerce and the economics of immediate gratification. Proceedings of the ACM Conference on Electronic Commerce, 5, 21-29. https://doi.org/10.1145/988772.988777

[4] Albarashdi, H. S. (2020). Social Networking ( SNS ) Addiction among University Students : A Literature Review and Research Directions. Journal of Education, Society and Behavioural Science, 33(1), 11-23. https://doi.org/10.9734/JESBS/2020/v33i130191

[5] Alhabash, S., Chiang, Y., \& Huang, K. (2014). MAM \& U\&G in Taiwan: Differences in the uses and gratifications of Facebook as a function of motivational reactivity. Computers in Human Behavior, 35, 423-430. https://doi.org/https://doi.org/10.1016/j.chb.2014.03.033

[6] Andreassen, C., \& Pallesen, S. (2013). Social Network Site Addiction - An Overview. Current Pharmaceutical Design, 20. https://doi.org/10.2174/13816128113199990616

[7] Balakrishnan, J., \& Griffiths, M. D. (2018). Loyalty towards online games, gaming addiction, and purchase intention towards online mobile in-game features. Computers in Human Behavior, 87, 238-246. https://doi.org/10.1016/J.CHB.2018.06.002 
[8] Balakrishnan, V., \& Shamim, A. (2013). Malaysian Facebookers: Motives and addictive behaviours unraveled. Computers in Human Behavior, 29(4), 1342-1349. https://doi.org/10.1016/j.chb.2013.01.010

[9] Balcerowska, J. M., Bereznowski, P., Biernatowska, A., Atroszko, P. A., Pallesen, S., \& Andreassen, C. S. (2020). Is it meaningful to distinguish between Facebook addiction and social networking sites addiction? Psychometric analysis of Facebook addiction and social networking sites addiction scales. Current Psychology, 1-14. Retrieved from https://link.springer.com/article/10.1007/s12144-020-00625-3

[10] Bandura, A. (1986). Social foundations of thought and action: A social cognitive theory.

[11] Bandura, A. (1991). Social Cognitive Theory of Self-Regulation. Organizational Behavior and Human Decision Processes, Vol. 50, pp. 248-287. https://doi.org/10.1111/j.14685957.1988.tb00115.x

[12] Bargeron, A. H., \& Hormes, J. M. (2017). Psychosocial correlates of internet gaming disorder: Psychopathology, life satisfaction, and impulsivity. Computers in Human Behavior, 68, 388394. https://doi.org/10.1016/j.chb.2016.11.029

[13] Baryła-Matejczuk, M., Skvarciany, V., Cwynar, A., Poleszak, W., \& Cwynar, W. (2020). Link between Financial Management Behaviours and Quality of Relationship and Overall Life Satisfaction among Married and Cohabiting Couples: Insights from Application of Artificial Neural Networks. International Journal of Environmental Research and Public Health, 17(4), 116. https://doi.org/10.3390/ijerph17041190

[14] Baumeister, R. F., \& Heatherton, T. F. (1996). Self-Regulation Failure: An Overview. 7(1), 115. Retrieved from http://citeseerx.ist.psu.edu/viewdoc/download?doi=10.1.1.460.2526\&rep=rep1\&type=pdf

[15] Błachnio, A., Przepiorka, A., Boruch, W., \& Bałakier, E. (2016). Self-presentation styles, privacy, and loneliness as predictors of Facebook use in young people. Personality and Individual Differences, 94, 26-31. https://doi.org/10.1016/j.paid.2015.12.051

[16] Błachnio, A., Przepiorka, A., \& Pantic, I. (2016). Association between Facebook addiction, selfesteem and life satisfaction: A cross-sectional study. Computers in Human Behavior, 55, 701705. https://doi.org/https://doi.org/10.1016/j.chb.2015.10.026

[17] Blackwell, D., Leaman, C., Tramposch, R., Osborne, C., \& Liss, M. (2017). Extraversion, neuroticism, attachment style and fear of missing out as predictors of social media use and addiction. Personality and Individual Differences, 116, 69-72. https://doi.org/10.1016/J.PAID.2017.04.039

[18] Böhnke, P. (2008). Does Society Matter? Life Satisfaction in the Enlarged Europe. Social Indicators Research, 87(2), 189-210. https://doi.org/10.1007/s11205-007-9169-4

[19] Bonds-Raacke, J., \& Raacke, J. (2010). Myspace and facebook: Identifying dimensions of uses and gratifications for friend networking sites. Individual Differences Research, 8(1), 27-33.

[20] Bozoglan, B., Demirer, V., \& Sahin, I. (2013). Loneliness, self-esteem, and life satisfaction as predictors of Internet addiction: A cross-sectional study among Turkish university students. Scandinavian Journal of Psychology, 54(4), 313-319. https://doi.org/10.1111/sjop.12049

[21] Brooks, S. (2015). Does personal social media usage affect efficiency and well-being? Computers in Human Behavior, 46, 26-37. https://doi.org/10.1016/j.chb.2014.12.053 
[22] Buyukbayraktar, C. G. (2020). Predictive Relationships Between Social Anxiety, Internet Addiction and Alexithymia in Adolescents. Journal of Education and Learning, 9(2), 222. https://doi.org/10.5539/jel.v9n2p222

[23] Caci, B., Cardaci, M., Scrima, F., \& Tabacchi, M. E. (2017). The Dimensions of Facebook Addiction as Measured by Facebook Addiction Italian Questionnaire and Their Relationships with Individual Differences. Cyberpsychology, Behavior, and Social Networking, 20(4), 251258.

[24] Caplan, S. E. (2010). Theory and measurement of generalized problematic Internet use: A twostep approach. Computers in Human Behavior, 26(5), 1089-1097. https://doi.org/https://doi.org/10.1016/j.chb.2010.03.012

[25] Capon, H., Hall, W., Fry, C., \& Carter, A. (2016). Realising the technological promise of smartphones in addiction research and treatment: An ethical review. International Journal of Drug Policy, 36, 47-57. https://doi.org/10.1016/j.drugpo.2016.05.013

[26] Carmon, A. F., Miller, A. N., \& Brasher, K. J. (2013). Privacy Orientations: A Look at Family Satisfaction, Job Satisfaction, and Work-Life Balance. Communication Reports, 26(2), 101112. https://doi.org/10.1080/08934215.2013.824017

[27] Casale, S., Rugai, L., \& Fioravanti, G. (2018). Exploring the role of positive metacognitions in explaining the association between the fear of missing out and social media addiction. Addictive Behaviors, 85(May), 83-87. https://doi.org/10.1016/j.addbeh.2018.05.020

[28] Chae, J. (2018). Reexamining the relationship between social media and happiness: The effects of various social media platforms on reconceptualized happiness. Telematics and Informatics, 35(6), 1656-1664. https://doi.org/10.1016/j.tele.2018.04.011

[29] Chan, M., Wu, X., Hao, Y., Xi, R., \& Jin, T. (2012). Microblogging, online expression, and political efficacy among young chinese citizens: The moderating role of information and entertainment needs in the use of weibo. Cyberpsychology, Behavior, and Social Networking, 15(7), 345-349. https://doi.org/10.1089/cyber.2012.0109

[30] Cheever, N. A., Moreno, M. A., \& Rosen, L. D. (2018). When Does Internet and Smartphone Use Become a Problem? In M. A. Moreno \& A. Radovic (Eds.), Technology and Adolescent Mental Health (pp. 121-131). Retrieved from https://link.springer.com/chapter/10.1007/978-3319-69638-6_10

[31] Chen, Y. (2017). WeChat use among Chinese college students: Exploring gratifications and political engagement in China. Journal of International and Intercultural Communication, 10(1), 25-43. https://doi.org/10.1080/17513057.2016.1235222

[32] Choi, I., Choi, H., Lim, J., Jung, S., Kim, J., \& Kim, J. (2019). Predictors of life satisfaction among multicultural African families in South Korea. Journal of Psychology in Africa, 29(1), 7-12. https://doi.org/10.1080/14330237.2019.1569301

[33] Clark, D. M., \& Wells, A. (1995). A cognitive model of social phobia. In Social phobia: Diagnosis, assessment, and treatment (pp. 69-93).

[34] Correa, T., Hinsley, A. W., \& de Zúñiga, H. G. (2010). Who interacts on the Web?: The intersection of users' personality and social media use. Computers in Human Behavior, 26(2), 247-253. https://doi.org/10.1016/J.CHB.2009.09.003 
[35] DATAREPORTAL. (2020). Social Media Users by Platform. Retrieved from DATAREPORTAL website: https://datareportal.com/social-media-users

[36] Davis, R. A. (2001). A cognitive-behavioral model of pathological Internet use. Computers in Human Behavior, 17(2), 187-195. https://doi.org/https://doi.org/10.1016/S07475632(00)00041-8

[37] de Bérail, P., Guillon, M., \& Bungener, C. (2019). The relations between YouTube addiction, social anxiety and parasocial relationships with YouTubers: A moderated-mediation model based on a cognitive-behavioral framework. Computers in Human Behavior. https://doi.org/10.1016/j.chb.2019.05.007

[38] DeCamp, W., \& Ferguson, C. J. (2017). The Impact of Degree of Exposure to Violent Video Games, Family Background, and Other Factors on Youth Violence. Journal of Youth and Adolescence, 46(2), 388-400. https://doi.org/10.1007/s10964-016-0561-8

[39] Denti, L., Barbopuolos, I., Nilsson, I., Holmberg, L., Thulin, M., Wendeblad, M., ... Davidsson, E. (2012). Sweden's largest Facebook study. [Online; Accessed 03-August- 2019], Gothenburg Research Institute. Retrieved from https://gupea.ub.gu.se/handle/2077/28893

[40] Diener, E. D., Emmons, R. A., \& Griffin, S. (1985). The satisfaction with life scale. Journal of Personality Assessment, 49(1), 71-75. Retrieved from http://citeseerx.ist.psu.edu/viewdoc/download?doi=10.1.1.470.1157\&rep=rep1\&type=pdf

[41] Diener, E., Suh, E. M., Lucas, R. E., \& Smith, H. L. (1999). Subjective well-being: Three decades of progress. Psychological Bulletin, 125(2), 276-302. https://doi.org/10.1037/00332909.125.2.276

[42] Dinev, T., \& Hart, P. (2006). An extended privacy calculus model for e-commerce transactions. Information Systems Research, 17(1), 61-80. https://doi.org/10.1287/isre.1060.0080

[43] Donnelly, E., \& Kuss, D. J. (2017). Depression among Users of Social Networking Sites (SNSs): The Role of SNS Addiction and Increased Usage. Journal of Addiction and Preventive Medicine, 02(01), 1-6. https://doi.org/10.19104/japm.2016.107

[44] Duncan, G. (2010). Should happiness-maximization be the goal of Government? Journal of Happiness Studies, 11(2), 163-178. https://doi.org/10.1007/s10902-008-9129-y

[45] Duradoni, M., Innocenti, F., \& Guazzini, A. (2020). Well-being and social media: A systematic review of Bergen Addiction Scales. Future Internet, 12(2), 1-12. https://doi.org/10.3390/fi12020024

[46] Ellison, N. B., Steinfield, C., \& Lampe, C. (2007). The benefits of facebook "friends:" Social capital and college students' use of online social network sites. Journal of Computer-Mediated Communication, 12(4), 1143-1168. https://doi.org/10.1111/j.1083-6101.2007.00367.x

[47] Elphinston, R. A., \& Noller, P. (2011). Time to face it! Facebook intrusion and the implications for romantic jealousy and relationship satisfaction. Cyberpsychology, Behavior and Social Networking, 14(11), 631-635. https://doi.org/10.1089/cyber.2010.0318

[48] Ferguson, C. J. (2017). Everything in Moderation: Moderate Use of Screens Unassociated with Child Behavior Problems. Psychiatric Quarterly, 88(4), 797-805. https://doi.org/10.1007/s11126-016-9486-3 
[49] Ferguson, C. J., \& Colwell, J. (2017). Understanding Why Scholars Hold Different Views on the Influences of Video Games on Public Health. Journal of Communication, 67(3), 305-327. https://doi.org/10.1111/jcom.12293

[50] Foroughi, B., Iranmanesh, M., Nikbin, D., \& Hyun, S. S. (2019). Are depression and social anxiety the missing link between Facebook addiction and life satisfaction? The interactive effect of needs and self-regulation. Telematics and Informatics, 43(June), 101247. https://doi.org/10.1016/j.tele.2019.101247

[51] Francis, G., Last, C. G., \& Strauss, C. Y. D. C. (1992). Avoidant Disorder and Social Phobia in Children and Adolescents. Journal of the American Academy of Child \& Adolescent Psychiatry, 31(6), 1086-1089. https://doi.org/https://doi.org/10.1097/00004583-199211000-00014

[52] Gámez-Guadix, M., Villa-George, F. I., \& Calvete, E. (2012). Measurement and analysis of the cognitive-behavioral model of generalized problematic Internet use among Mexican adolescents. Journal of Adolescence, 35(6), 1581-1591. https://doi.org/https://doi.org/10.1016/j.adolescence.2012.06.005

[53] Griffiths, M., Miller, H., Gillespie, T., \& Sparrow, P. (1999). Internet usage and "internet addiction" in students and its implications for learning. Journal of Computer Assisted Learning, 15(1), 85-90. https://doi.org/10.1046/j.1365-2729.1999.t01-2-151078.x

[54] Hair, J. ., Black, W. ., Babin, J. ., Anderson, R. ., \& Tatham, R. . (2010). Multivariate data analysis (7th ed., Vol. 1). https://doi.org/10.1007/978-94-009-3789-5

[55] Heatherton, T. F. (2011). Neuroscience of Self and Self-Regulation. Annual Review of Psychology, 62(1), 363-390. https://doi.org/10.1146/annurev.psych.121208.131616

[56] Hofmann, W., Friese, M., \& Strack, F. (2009). Impulse and Self-Control From a Dual-Systems Perspective. Perspectives on Psychological Sciences, 4(2), 162.

[57] Hofstede, G. (2014). The 6-D model of national culture.

[58] Hong, W., \& Thong, J. Y. L. (2013). Research Note Internet Privacy Concerncs: An Integrated Example Items from Existing IPC Instruments. MIS Quarterly, 37(1), 275-298.

[59] Hussain, Z., Williams, G. A., \& Griffiths, M. D. (2015). An exploratory study of the association between online gaming addiction and enjoyment motivations for playing massively multiplayer online role-playing games. Computers in Human Behavior, 50, 221-230. https://doi.org/10.1016/j.chb.2015.03.075

[60] Inderbitzen-Nolan, H. M., \& Walters, K. S. (2000). Social Anxiety Scale for Adolescents: Normative Data and Further Evidence of Construct Validity. Journal of Clinical Child Psychology, 29(3), 360-371. https://doi.org/10.1207/S15374424JCCP2903

[61] Ivanova, K. (2020). My Children, Your Children, Our Children, and My Well-Being: Life Satisfaction of "Empty Nest" Biological Parents and Stepparents. Journal of Happiness Studies, 21(2), 613-633. https://doi.org/10.1007/s10902-019-00097-8

[62] Jørgensen, S. E., Thygesen, L., Andersen, A., Due, P., \& Michelsen, S. (2020). Parental illness and life satisfaction among adolescents. A cross-sectional study of moderating effects of school climate indicators. https://doi.org/10.21203/rs.3.rs-20066/v1

[63] Kaiser, H. F. (1958). The varimax criterion for analytic rotation in factor analysis. Psychometrica, 23(2), 187-200. 
[64] Kang, I., Shin, M. M., \& Park, C. (2013). Internet addiction as a manageable resource: A focus on social network services. Online Information Review, 37(1), 28-41. https://doi.org/10.1108/14684521311311612

[65] Kim, C., \& Shen, C. (2020). Connecting activities on Social Network Sites and life satisfaction: A comparison of older and younger users. Computers in Human Behavior, 105. https://doi.org/https://doi.org/10.1016/j.chb.2019.106222

[66] Kuss, D. J., \& Griffiths, M. D. (2011). Online Social Networking and Addiction-A Review of the Psychological Literature. International Journal of Environmental Research and Public Health, 8(9), 3528-3552. https://doi.org/10.3390/ijerph8093528

[67] Kuss, D. J., \& Griffiths, M. D. (2017). Social networking sites and addiction: Ten lessons learned. International Journal of Environmental Research and Public Health, 14(3). https://doi.org/10.3390/ijerph14030311

[68] Kuss, D. J., Shorter, G. W., van Rooij, A. J., Griffiths, M. D., \& Schoenmakers, T. M. (2014). Assessing Internet Addiction Using the Parsimonious Internet Addiction Components ModelA Preliminary Study. International Journal of Mental Health and Addiction, 12(3), 351-366. https://doi.org/10.1007/s11469-013-9459-9

[69] Laufer, R. S., \& Wolfe, M. (1977). Privacy as a Concept and a Social Issue: A Multidimensional Developmental Theory. Journal of Social Issues, 33(3), 22-42. Retrieved from https://spssi.onlinelibrary.wiley.com/doi/abs/10.1111/j.1540-4560.1977.tb01880.x

[70] LeadsKuwait. (2020). Snapchat Marketing in Kuwait.

[71] Lee, J. yeon, Ko, D. W., \& Lee, H. (2019). Loneliness, regulatory focus, inter-personal competence, and online game addiction: A moderated mediation model. Internet Research. https://doi.org/10.1108/IntR-01-2018-0020

[72] Lee, M. S., Oh, E. Y., Cho, S. M., Hong, M. J., \&, \& Moon, J. S. (2001). An assessment of adolescent Internet addiction problems related to depression, social anxiety and peer relationship. Ournal of Korean Neuropsychiatric Association, 40(4), 616-628.

[73] Leversen, I., Danielsen, A. G., Birkeland, M. S., \& Samdal, O. (2012). Basic Psychological Need Satisfaction in Leisure Activities and Adolescents' Life Satisfaction. Journal of Youth and Adolescence, 41(12), 1588-1599. https://doi.org/10.1007/s10964-012-9776-5

[74] Lin, C. A. (1996). Looking back: The contribution of Blumler and Katz's uses of mass communication to communication research. Journal of Broadcasting \& Electronic Media, 40(4), 574-581. https://doi.org/10.1080/08838159609364379

[75] Lin, S., Liu, D., Niu, G., \& Longobardi, C. (2020). Active Social Network Sites Use and Loneliness: the Mediating Role of Social Support and Self-Esteem. Curr Psychol.

[76] Lombardo, P., Jones, W., Wang, L., Shen, X., \& Goldner, E. M. (2018). The fundamental association between mental health and life satisfaction: Results from successive waves of a Canadian national survey. BMC Public Health, 18(1), 1-9. https://doi.org/10.1186/s12889-018$5235-\mathrm{x}$

[77] Longstreet, P., Brooks, S., \& Gonzalez, E. S. (2018). Internet addiction: When the positive emotions are not so positive. Technology in Society, (November), 1-10. https://doi.org/10.1016/j.techsoc.2018.12.004 
[78] Masur, P. K., Reinecke, L., Ziegele, M., \& Quiring, O. (2014). The interplay of intrinsic need satisfaction and Facebook specific motives in explaining addictive behavior on Facebook. Computers in Human Behavior, 39, 376-386. https://doi.org/10.1016/j.chb.2014.05.047

[79] Mingchuan, G., Mengli, X., Adeel, L., Lingling, Y., \& Ayesha, M. (2020, January 1). Understanding the role of individual differences in mobile SNS addiction. Kybernetes. https://doi.org/10.1108/K-05-2019-0367

[80] Nayeri, N. D., \& Aghajani, M. (2010). Patients' privacy and satisfaction in the emergency department: A descriptive analytical study. Nursing Ethics, 17(2), 167-177. https://doi.org/10.1177/0969733009355377

[81] Neugarten, B. L., Havighurst, R. J., \& Tobin, S. S. (1961). The Measurement of Life Satisfaction. Journal of Gerontology, 16(3), 134-143. https://doi.org/https://doi.org/10.1093/geronj/16.2.134

[82] Ngoo, Y. T., Tey, N. P., \& Tan, E. C. (2015). Determinants of Life Satisfaction in Asia. Social Indicators Research, 124(1), 141-156. https://doi.org/10.1007/s11205-014-0772-x

[83] O'Toole, M. S., Hougaard, E., \& Mennin, D. S. (2013). Social anxiety and emotion knowledge: A meta-analysis. Journal of Anxiety Disorders, 27(1), 98-108. https://doi.org/10.1016/j.janxdis.2012.09.005

[84] Ott, J. (2013). Science and Morality: Mind the Gap, Use Happiness as a Safe Bridge! Journal of Happiness Studies, 14(1), 345-351. https://doi.org/10.1007/s10902-012-9327-5

[85] Özdemir, Y., Kuzucu, Y., \& Ak, S. (2014). Author' s personal copy Computers in Human Behavior Depression, loneliness and Internet addiction: How important is low. Computers in Human Behavior Journal, 34, 284-290. https://doi.org/10.1016/j.chb.2014.02.009

[86] Papacharissi, Z., \& Mendelson, A. (2010). 12 Toward a new (er) sociability: uses, gratifications and social capital on Facebook. In Media perspectives for the 21st century.

[87] Pedersen, P. E., \& Ling, R. (2003). Modifying adoption research for mobile Internet service adoption: Cross-disciplinary interactions. Proceedings of the 36th Annual Hawaii International Conference on System Sciences, HICSS 2003, 00(C), 1-10. https://doi.org/10.1109/HICSS.2003.1174217

[88] Pentina, I., Zhang, L., Bata, H., \& Chen, Y. (2016). Exploring privacy paradox in informationsensitive mobile app adoption: A cross-cultural comparison. Computers in Human Behavior, 65, 409-419. https://doi.org/10.1016/j.chb.2016.09.005

[89] Phu, B., \& Gow, A. J. (2019). Facebook use and its association with subjective happiness and loneliness. Computers in Human Behavior, 92(November), 151-159. https://doi.org/10.1016/j.chb.2018.11.020

[90] Plopa, M. (2020). Partners' Sexual Satisfaction in Partnership and Marriage: A Study Method. Journal of Sex \& Marital Therapy, 46(1), 78-98. https://doi.org/10.1080/0092623X.2019.1654578

[91] Ponnusamy, S., Iranmanesh, M., \& Foroughi, B. (2020). Drivers and outcomes of Instagram Addiction: Psychological well-being as moderator. Computers in Human Behavior2, 107. Retrieved from https://www.sciencedirect.com/science/article/pii/S0747563220300492 
[92] Pornsakulvanich, V., Haridakis, P., \& Rubin, A. (2008). The influence of dispositions and Internet motivation on online communication satisfaction and relationship closeness. Computers in Human Behavior, 24, 2292-2310. https://doi.org/10.1016/j.chb.2007.11.003

[93] Prasoon, R., \& Chaturvedi, K. R. (2016). Life Satisfaction: A Literature Review. The Researcher-International Journal of Management, Humanities and Social Sciences, 1(2), 25-32. Retrieved from http://theresearcherjournal.org/pdfs/01021220163.pdf

[94] Przybylski, A. K. (2014). Electronic gaming psychosocial adjustment. Pediatrics, 134(3), e716e722. https://doi.org/10.1542/peds.2013-4021

[95] Punyanunt-Carter, N. M., De La Cruz, J. J., \& Wrench, J. S. (2017). Investigating the relationships among college students' satisfaction, addiction, needs, communication apprehension, motives, and uses \& gratifications with Snapchat. Computers in Human Behavior, 75, 870-875. https://doi.org/https://doi.org/10.1016/j.chb.2017.06.034

[96] Radloff, L. S. (1977). A Self-Report Depression Scale for Research in the General Population. Appl. Psychol. Meas., 1(3), 385-401. https://doi.org/10.1177/014662167700100306

[97] Rapee, R. M., \& Heimberg, R. G. (1997). A cognitive-behavioral model of anxiety in social phobia. Behaviour Research and Therapy, 35(8), 741-756.

[98] Sanders, B., Chen, V., Zahra, D., Dowland, P., Atkinson, S., Papadaki, M., \& Furnell, S. (2010). Online addiction: Privacy risks in online gaming environments. Proceedings of the International Conference on Management of Emergent Digital EcoSystems, MEDES'10, 114-121. https://doi.org/10.1145/1936254.1936275

[99] Saquib, J. (2020). Internet addiction among Saudi Arabian youth. International Journal of Health Sciences, 14(2). Retrieved from file:///Users/hasan/Downloads/4795-Title page (contains names, affiliation, corresponding author)-16187-1-10-20200229.pdf

[100] Schmeichel, B. J., \& Zell, A. (2007). Trait self-control predicts performance on behavioral tests of self-control. Journal of Personality, 75(4), 743-756. https://doi.org/10.1111/j.14676494.2007.00455.x

[101] Shahnaz, I., \& Karim, A. K. M. R. (2014). The Impact of Internet Addiction on Life Satisfaction and Life Engagement in Young Adults. Universal Journal of Psychology, 2(9), 273-284. https://doi.org/10.13189/ujp.2014.020902

[102] Shin, D. C., \& Johnson, D. M. (1978). Avowed happiness as an overall assessment of the quality of life. Social Indicators Research, 5(1-4), 475-492. https://doi.org/10.1007/BF00352944

[103] Sioni, S. R., Burleson, M. H., \& Bekerian, D. A. (2017). Internet gaming disorder: Social phobia and identifying with your virtual self. Computers in Human Behavior, 71, 11-15. https://doi.org/10.1016/j.chb.2017.01.044

[104] Slater, M. D. (2003). Alienation, aggression, and sensation seeking as predictors of adolescent use of violent film, computer, and website content. Journal of Communication, 53(1), 105-121.

[105] Smith, H. J., Milberg, S. J., \& Burke, S. J. (1996). Information Privacy: Measuring Individuals' Concerns about Organizational Practices. MIS Quarterly, 20(2), 167-196.

[106] Social Media Insights. (2019). Social Media Platforms Usage in Kuwait 2019| WeAreSocial. 
[107] Stieger, S., Burger, C., Bohn, M., \& Voracek, M. (2013). Who commits virtual identity suicide? Differences in privacy concerns, internet addiction, and personality between facebook users and quitters. Cyberpsychology, Behavior, and Social Networking, 16(9), 629-634. https://doi.org/10.1089/cyber.2012.0323

[108] Strulik, H. (2019). An economic theory of depression and its impact on health behavior and longevity. Journal of Economic Behavior \& Organization, 158, 269-287. https://doi.org/10.1016/J.JEBO.2018.11.022

[109] Sumner, W. (1996). Welfare, happiness, and ethics. Oxford: Clarendon Press.

[110] Tangney, J. P., Boone, A. L., \& Baumeister, R. F. (2004). High self-control predicts good adjustment, less pathology, better grades, and interpersonal success. Self-Regulation and SelfControl: Selected Works of Roy F. Baumeister, 72(2, April 2004), 173-212. https://doi.org/10.4324/9781315175775

[111] The Information and Communication Revolution and International Relations. (2017). In The International Studies Encyclopedia\$ The International Studies Encyclopedia. Retrieved from https://annenberg.usc.edu/sites/default/files/2015/08/11/The_Information_and_Communicatio n_Revolution_and_International_Relations_0.pdf

[112] Tosun, L. P., \& Lajunen, T. (2009). Why Do Young Adults Develop a Passion for Internet ““ True Self "' on the Internet, and Passion for the Internet. CyberPsychology \& Behavior, 12(4), 401-406.

[113] Vancea, M., Shore, J., \& Utzet, M. (2019). Role of employment-related inequalities in young adults' life satisfaction: A comparative study in five European welfare state regimes. Scandinavian Journal of Public Health, 47(3), 357-365.

[114] Wang, J.-L., Sheng, J.-R., \& Wang, H.-Z. (2019). The Association Between Mobile Game Addiction and Depression, Social Anxiety, and Loneliness. Frontiers in Public Health, 7(September), 5-10. https://doi.org/10.3389/fpubh.2019.00247

[115] Warda, H. M. A. (2020). The effectiveness of life skills program in enhancing students' lifesatisfaction and self-efficacy among female students in Al Majmaah University. Journal of Research in Curriculum, Instruction and Educational Technology, 6(1), 29-34.

[116] Weeks, J. W., Heimberg, R. G., Hart, T. A., Fresco, D. M., Turk, C. L., Schneier, F. R., \& Liebowitz, M. R. (2005). Empirical validation and psychometric evaluation of the brief fear of negative evaluation scale in patients with social anxiety disorder. Psychological Assessment, 17(2), 179-190. https://doi.org/10.1037/1040-3590.17.2.179

[117] Weijs-Perrée, M., Van den Berg, P., Arentze, T., \& Kemperman, A. (2015). Factors influencing social satisfaction and loneliness: A path analysis. Journal of Transport Geography, 45, 24-31. https://doi.org/10.1016/j.jtrangeo.2015.04.004

[118] Wolniewicz, C. A., Tiamiyu, M. F., Weeks, J. W., \& Elhai, J. D. (2018). Problematic smartphone use and relations with negative affect, fear of missing out, and fear of negative and positive evaluation. Psychiatry Research, 262(September 2017), 618-623. https://doi.org/10.1016/j.psychres.2017.09.058

[119] Young, K. S. (2004). Internet addiction: A new clinical phenomenon and its consequences. American Behavioral Scientist, 48(4), 402-415. https://doi.org/10.1177/0002764204270278 
[120] Young, K. S., \& Rodgers, R. C. (1998). The Relationship Between Depression and Internet Addiction. CyberPsychology \& Behavior, 1(1), 25-28. https://doi.org/10.1089/cpb.1998.1.25

[121] Zhang, S., Kwok, R. C.-W., Lowry, P. B., Liu, Z., \& Wu, J. (2019). The influence of role stress on self-disclosure on social networking sites: A conservation of resources perspective. $\begin{array}{llll}\text { Information } \quad \text { M } & \text { Management, } & \text { 56(7), }\end{array}$ https://doi.org/https://doi.org/10.1016/j.im.2019.02.002

[122] Zhao, S., Zhang, J., Liu, Y., Ji, H., \& Lew, B. (2020). The association between psychological strains and life satisfaction: Evidence from medical staff in China. Journal of Affective Disorders, 260(September), 105-110. https://doi.org/10.1016/j.jad.2019.09.006

[123] Zimbardo, P. G. (1977). Shyness: What it is, What to do about it? Sydney: Addison-Wesley Publishing Company.

[124] Zlatolas, L. N., Welzer, T., Heričko, M., \& Hölbl, M. (2015). Privacy antecedents for SNS selfdisclosure: The case of Facebook. Computers in Human Behavior, 45, 158-167. https://doi.org/10.1016/j.chb.2014.12.012

[125] Zullig, K. J., \& White, R. J. (2011). Physical Activity, Life Satisfaction, and Self-Rated Health of Middle School Students. Applied Research in Quality of Life, 6(3), 277-289. https://doi.org/10.1007/s11482-010-9129-z

\section{APPENDIX}

\begin{tabular}{|l|l|l|}
\hline Privacy & & \\
\hline & $\mathrm{PR}_{1}$ & $\begin{array}{l}\text { I am concerned that mobile applications developers do not devote enough time } \\
\text { and effort to preventing unauthorized access to my personal information. }\end{array}$ \\
\hline & $\mathrm{PR}_{2}$ & $\begin{array}{l}\text { I am concerned that when I give personal information to a mobile application } \\
\text { for some reason, the application would use the information for other reasons. }\end{array}$ \\
\hline & $\mathrm{PR}_{3}$ & $\begin{array}{l}\text { It usually bothers me when I am not aware or knowledgeable about how my } \\
\text { personal information will be used by mobile applications providers. }\end{array}$ \\
\hline & $\mathrm{PR}_{4}$ & $\begin{array}{l}\text { It usually bothers me when mobile applications ask me for personal } \\
\text { information. }\end{array}$ \\
\hline & $\mathrm{PR}_{5}$ & $\begin{array}{l}\text { It usually bothers me when I do not have control or autonomy over decisions } \\
\text { about how my personal information is collected, used, and shared by mobile } \\
\text { applications. }\end{array}$ \\
\hline & $\mathrm{PR}_{6}$ & $\begin{array}{l}\text { I am concerned that mobile applications providers do not have adequate } \\
\text { procedures to correct errors in my personal information. }\end{array}$ \\
\hline Recognition needs & & To establish my personal identity. \\
\hline & $\mathrm{RN}_{1}$ & To \\
\hline & $\mathrm{RN}_{2}$ & To gain respect and support. \\
\hline & $\mathrm{RN}_{3}$ & To build up my confidence. \\
\hline & $\mathrm{RN}_{4}$ & Because it is satisfying. \\
\hline & $\mathrm{RN}_{5}$ & To promote or publicize my expertise. \\
\hline & & \\
\hline Social needs & $\mathrm{SN}_{1}$ & To express my feeling. \\
\hline & $\mathrm{SN}_{2}$ & To share my views, thoughts, and experience. \\
\hline & $\mathrm{SN}_{3}$ & To stay in touch with people I know. \\
\hline & $\mathrm{SN}_{4}$ & To get peer support from others. \\
\hline & $\mathrm{SN}_{5}$ & To meet interesting people. \\
\hline & & \\
\hline Entertainment needs & $\mathrm{EN}_{1}$ & To pass time. \\
\hline & $\mathrm{EN}_{2}$ & Because I am curious. \\
\hline & $\mathrm{EN}_{3}$ & Because it is entertaining. \\
\hline & $\mathrm{EN}_{4}$ & Because it is funny. \\
\hline & $\mathrm{EN}_{5}$ & Because it is trendy. \\
\hline & &
\end{tabular}


Life satisfaction as defined by Snapchat usage and addiction Case study in Kuwait

\begin{tabular}{|c|c|c|}
\hline \multicolumn{3}{|l|}{ Fear of negative eval. } \\
\hline & $\mathrm{FNE}_{1}$ & I'm afraid that others will not like me. \\
\hline & $\mathrm{FNE}_{2}$ & I worry about what others think of me. \\
\hline & $\mathrm{FNE}_{3}$ & I worry what others say about me. \\
\hline & $\mathrm{FNE}_{4}$ & I worry that others don't like me. \\
\hline & $\mathrm{FNE}_{5}$ & I worry about being teased. \\
\hline & $\mathrm{FNE}_{6}$ & I feel that others are making fun of me. \\
\hline & $\mathrm{FNE}_{7}$ & I feel that peers talk about me behind my back. \\
\hline & $\mathrm{FNE}_{8}$ & If I get into an argument, I worry that the other person will not like me. \\
\hline \multicolumn{3}{|r|}{ 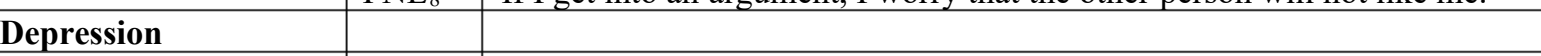 } \\
\hline & $\mathrm{DEP}_{1}$ & I was bothered by things that usually don't bother me. \\
\hline & $\mathrm{DEP}_{2}$ & I did not feel like eating; my appetite was poor. \\
\hline & $\mathrm{DEP}_{3}$ & $\begin{array}{l}\text { I felt that I could not shake off the blues even with help from my family or } \\
\text { friends. }\end{array}$ \\
\hline & $\mathrm{DEP}_{4}$ & I felt that I was just as good as other people. \\
\hline & $\mathrm{DEP}_{5}$ & I had trouble keeping my mind on what I was doing. \\
\hline & $\mathrm{DEP}_{6}$ & I felt depressed. \\
\hline & $\mathrm{DEP}_{7}$ & I felt that everything I did was an effort. \\
\hline & $\mathrm{DEP}_{8}$ & I felt hopeful about the future. \\
\hline & $\mathrm{DEP}_{9}$ & I thought my life had been a failure. \\
\hline & $\mathrm{DEP}_{10}$ & I felt fearful \\
\hline & $\mathrm{DEP}_{11}$ & My sleep was restless. \\
\hline & $\mathrm{DEP}_{12}$ & I was happy. \\
\hline & $\mathrm{DEP}_{13}$ & I talked less than usual. \\
\hline & $\mathrm{DEP}_{14}$ & I felt lonely. \\
\hline & $\mathrm{DEP}_{15}$ & People were unfriendly. \\
\hline & $\mathrm{DEP}_{16}$ & I enjoyed life. \\
\hline & $\mathrm{DEP}_{17}$ & I had crying spells. \\
\hline & $\mathrm{DEP}_{18}$ & I felt sad. \\
\hline & $\mathrm{DEP}_{19}$ & I felt that people dislike me. \\
\hline & $\mathrm{DEP}_{20}$ & I could not get "going." \\
\hline \multicolumn{3}{|l|}{ Addiction } \\
\hline & $\mathrm{ADD}_{1}$ & Did you think about using Snapchat all day long? \\
\hline & $\mathrm{ADD}_{2}$ & Did you spend a large amount of free time on Snapchat? \\
\hline & $\mathrm{ADD}_{3}$ & Have you felt addicted to Snapchat? \\
\hline & $\mathrm{ADD}_{4}$ & Did you use Snapchat longer than intended? \\
\hline & $\mathrm{ADD}_{5}$ & Did you spend increasing amount of time using Snapchat? \\
\hline & $\mathrm{ADD}_{6}$ & Were you unable to stop once you started using Snapchat? \\
\hline & $\mathrm{ADD}_{7}$ & Did you use Snapchat to forget about real life? \\
\hline & $\mathrm{ADD}_{8}$ & Have you used Snapchat to release stress? \\
\hline & $\mathrm{ADD}_{9}$ & Have you used Snapchat to feel better? \\
\hline & $\mathrm{ADD}_{10}$ & Were you unable to reduce your Snapchat use? \\
\hline & $\mathrm{ADD}_{11}$ & Have others unsuccessfully tried to reduce your Snapchat use? \\
\hline & $\mathrm{ADD}_{12}$ & Have you failed when trying to reduce Snapchat time? \\
\hline & $\mathrm{ADD}_{13}$ & Have you felt bad when you were unable to use Snapchat? \\
\hline & $\mathrm{ADD}_{14}$ & Have you become angry when unable to use Snapchat? \\
\hline & $\mathrm{ADD}_{15}$ & Have you become stressed when unable to use Snapchat? \\
\hline & $\mathrm{ADD}_{16}$ & Did you have fights with others over your time spent on Snapchat? \\
\hline & $\mathrm{ADD}_{17}$ & Have you neglected others because you were using Snapchat? \\
\hline & $\mathrm{ADD}_{18}$ & Have you lied about time spent on using Snapchat? \\
\hline & $\mathrm{ADD}_{19}$ & Has your time on Snapchat caused sleep deprivation? \\
\hline & $\mathrm{ADD}_{20}$ & Have you neglected other important activities? \\
\hline & $\mathrm{ADD}_{21}$ & Did you feel bad after using Snapchat for a long time? \\
\hline
\end{tabular}

